\title{
Nitrogen cycling in an estuarine upwelling system, the Ría de Arousa (NW Spain). II. Spatial differences in the short-time-scale evolution of fluxes and net budgets
}

\author{
X. A. Alvarez-Salgado*, G. Rosón, F. F. Pérez, F. G. Figueiras, A. F. Ríos \\ Instituto de Investigacións Mariñas, Consejo Superior de Investigaciones Científicas (CSIC), Eduardo Cabello 6 , \\ E-36208 Vigo, Spain
}

\begin{abstract}
Coupling between residual estuarine circulation and nitrogen biogeochemistry in the Ria de Arousa (NW Spain) was studied in 4 characteristic hydrographic regimes during the upwelling season. The characteristics of each regime are as follows: (1) In upwelling conditions after a pronounced stratification of the water column, vertical transport of nitrate to the photic layer occurs mainly by advection. Nitrate is instantaneously taken up by autotrophs, making the ria an efficient nutrient-salt trap. High net community production (194 $\mathrm{mg} \mathrm{N} \mathrm{m}^{-2} \mathrm{~d}^{-1}$ ) occurs in the whole water column. Nitrogen partitioning favours the particulate organic nitrogen pool in the upper layer and the dissolved organic nitrogen pool in the lower layer, while $1 / 3$ of the net community production settles to the bottom. (2) When stratification is low prior to upwelling, vertical mixing prevails, upwelled nutrients are retained only by hydrodynamic accumulation, and the efficiency of the ria as a nutrient-salt trap clearly diminishes. In this situation net uptake by phytoplankton is delayed due to the low biomass in newly upwelled waters, and to the lag time for adaptation to the nutrient and light conditions. (3) During prolonged periods of upwelling relaxation, high water column stability develops and vertical transport is limited. The low net community production in the upper layer $\left(80 \mathrm{mg} \mathrm{N} \mathrm{m} \mathrm{N}^{-1}\right.$ ) is supported entirely by nutrients regenerated in the lower layer and at the sediment-water interface from sinking organic matter (only $3 \%$ of the particulate organic matter produced is exported to the shelf). (4) Finally, during strong autumn downwelling, nutrient-poor shelf surface waters enter the inner ria and meet the ammonium-rich waters flowing out from the Ulla estuary. This advected ammonium and the ammonium diffused from the sediments is transported to the bottom layer over the shelf by reversed residual circulation. High sedimentation rates result from intense transport of particulate matter to the lower layer
\end{abstract}

KEY WORDS: Nitrogen speciation - Rias Basxas (NW Spain) Hydrodynamic-biogeochemical coupling

\section{INTRODUCTION}

This work is the continuation of a previous study on the cycling of nitrogen species in the largest of the 4 Rías Baixas (NW Spain) during the period when estuarine hydrodynamics are controlled by coastal upwelling. The relative influence of the physical and biological conditions on fluxes and net biogeochemical budgets of nitrogen in the central part of the ría was evaluated. The variahility imnnsed hy wind stress oyer the adjacent shelf on the residual water circulation,

·E-mail: xsalgado@nautilus.iim.csic.es and the strong influence of an intensive hanging culture of edible mussels on the redistribution of uptaken nutrient salts among the different nitrogen pools, determine the complex nitrogen biogeochemistry of this ecosystem (Alvarez-Salgado et al. 1996-this issue).

In this second work we deal with some relevant details that have been neglected in the companion paper. Here, new subjects such as the relative contribution of the 'entrainment.' of layers in the transport of nitrogen to the photic zone, the importance of hydro. dynamic accumulation versus net uptake by the community of organisms and the short-time-scale coupling between input and net uptake of external nitrogen are 

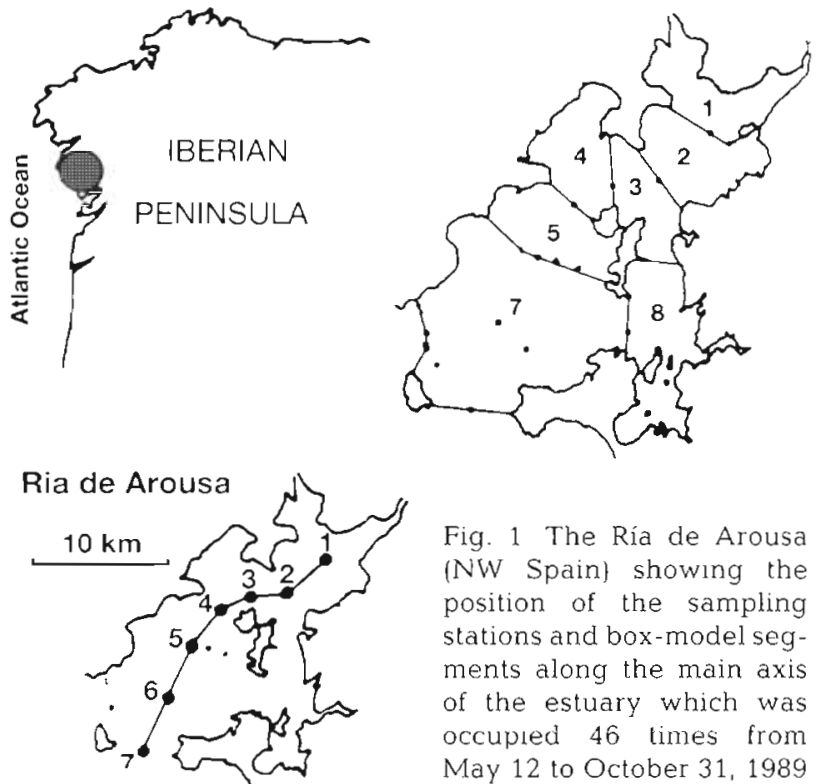

Fig. 1 The Ría de Arousa (NW Spain) showing the position of the sampling stations and box-model segments along the main axis of the estuary which was occupled 46 times from May 12 to October 31, 1989

addresed. The work focuses on 4 characteristic hydrographic situations that were selected from the range of scenarios found in the Ría de Arousa during the study period; these scenarios are summarized in the stratification-circulation diagram of the companion paper (Fig. 5 in Alvarez-Salgado 1996) and described below.

Hydrography and nitrogen species distributions along the main axis of the estuary were studied (Fig. 1) during the different regimes of a complete upwelling cycle. The first scenario we examined followed a period of high water column stability, from June 26 to July 17 (Surveys 10 to 16) in. 1989. We also investigated the effect of upwelling on a less stratified water column owing to a decrease in both river discharge and heat gain, as occurred from August 31 to September 11 (Surveys 29 to 32). The third scenario studied corresponds to a long period in non-wind-forced conditions with very slow residual circulation and strong stratification between August 7 and 17 (Surveys 22 to 25). Finally, from October 13 to 30 (Surveys 41 to 46 ) we recorded a characteristic autumn downwelling event, with a reversal in estuarine circulation. The spatial differences in the distributions of average water flows and nitrogen species fluxes, as well as biogeochemical budgets, are examined for each of the situations studied

\section{MATERIALS AND METHODS}

Ten stations were occupied twice a week in the Ría de Arousa during the 1989 upwelling season. Water samples were drawn from 5 to 7 depths with Niskin bottles provided with reversing thermometers. A brief description of the methods is included below. (See Alvarez-
Salgado et al. 1996 for a detailed description of sampling, analytical details and box model calculations.)

Salinity was determined with an AUTOSAL 8400A. Nutrients were analysed on board with Technicon AAIl systems. Particulate organic nitrogen, collected over Whatman GF/F filters, was analysed using a PE2400 CHN elemental analyser. The Bakun's upwelling index $\left(I_{w}\right)$ was calculated from wind data taken at the Cape Finisterre Meteorological Observatory according to Wooster et al. (1976). Upper $\left(Q_{X}\right)$ and lower $\left(Q_{X_{0}}\right)$ layer opposite horizontal residual flows and vertical exchange between both layers by advection $\left(Q_{z}\right)$ and turbulent diffusion $\left(M_{z}\right)$ were taken from Rosón et al (in press). Average horizontal $\left(v_{x 0}, v_{X}\right)$ and vertical $\left(v_{z}\right)$ residual velocity fields and the velocity of vertical mixing $\left(v_{M}\right)$ were calculated considering the geometry of the ría (Table 1 in Alvarez-Salgado et al. 1996). The latter can be related to an averaged-overbox vertical diffusion coefficient $\left(k_{z}\right)$ by using the simple equation $k_{Z}=v_{M}(Z / 2)$, with $Z$ being the mean depth of the box.

In each layer, the net budget of inputs and outputs $(i-O)$ for a nitrogen form $(N)$ can be calculated as:

$$
\mathrm{i}-\mathrm{o}=\frac{\partial(N \cdot V)}{\partial t}-\delta N=\sum_{i} Q_{i} \cdot N_{i}+M_{2} \cdot d N_{\mathrm{L}}+R \cdot N_{\mathrm{R}}
$$

where $t$ is time; $Q_{1}$ is volume $\left(\mathrm{m}^{3} \mathrm{~s}^{-1}\right)$ and $N_{1}$ is concentration of $\mathrm{N}\left(\mathrm{mol} \mathrm{m}^{-3}\right)$ carried by the convective flow $i$; $d N_{\mathrm{L}}$ is the difference in concentration between the upper and lower layer; $R$ and $N_{R}$ represent water flow and concentration of $\mathrm{N}$ in continental runoff to the box; $V$ is the volume of the layer $\left(\mathrm{m}^{3}\right)$ and $\delta N$ is the net increase of $\mathrm{N}$ by biogeochemical processes.

The net budget for $\mathrm{N}$ between Surveys $j-1$ and $j$ (I O) can be obtained by integrating Eq. (1) from $t_{j-1}$ to $t_{j}$ :

$$
\begin{aligned}
\mathrm{I}-\mathrm{O} & =N_{t_{j}} \cdot V_{t_{j}}-N_{i_{j-1}} V_{t_{j-1}}-\Delta N \\
& =\int_{t_{1-1}}^{t_{1}} \sum_{i} Q_{i} \cdot N_{i} \cdot \mathrm{d} t+\int_{t_{1-1}}^{t_{j}} M \cdot d N_{\mathrm{L}} \cdot \mathrm{d} t+\int_{t_{j-1}}^{t_{1}} R \cdot N_{\mathrm{R}} \cdot \mathrm{d} t
\end{aligned}
$$

where $\Delta N$ is the biogeochemical budget $(\delta N)$ integrated between $t_{j-1}$ and $t_{j}$

The flux $\left(F_{1}\right)$ of any nitrogen form $\left(N_{t}\right)$ carried by the flow $Q_{i}$ between Surveys $t_{j-1}$ and $t_{j}$ can be simply calculated as:

$$
\begin{aligned}
F_{i} & =\int_{t_{i-1}}^{t_{1}} Q_{1} N_{i} \mathrm{~d} t \\
& =\frac{1}{6}\left[Q_{i, t_{j-1}} \cdot N_{t_{j-1}}+2 Q_{i, t_{m}}\left(N_{t_{j-1}}+N_{t_{j}}\right)+Q_{i, t_{j}} \cdot N_{i_{j}}\right]
\end{aligned}
$$

if salinity, temperature, $N_{i}, N_{\mathrm{R}}$ and $R$ are assumed to change linearly between $t_{j-1}$ and $t_{j}$. $Q_{L_{1} t_{m}}$ is the residual flow $i$ at $t=0.5\left(t_{j}+t_{j-1}\right)$, calculated by solving Eq. (2) for the thermohaline properties $(\Delta N=0)$. The same kind of 
calculation can be appiied to obtain the flow of $N$ carried by $M_{z}$

$\triangle D I N, \triangle D O N$ and $\triangle P O N$ can be obtained by solving Eq. (2) for the DIN (dissolved inorganic N), DON (dissolved organic $\mathrm{N}$ ) and PON (particulate organic $\mathrm{N}$ ) pools respectively. $-\Delta \mathrm{DIN} /\left(t_{j}-t_{j-1}\right)$ represents the net community production (NCP) of the ecosystem inside the volume considered between 2 consecutive surveys. $\triangle \mathrm{PON}$ must be calculated as:

$$
\triangle P O N=-\Delta D I N-\triangle D O N-E_{N}
$$
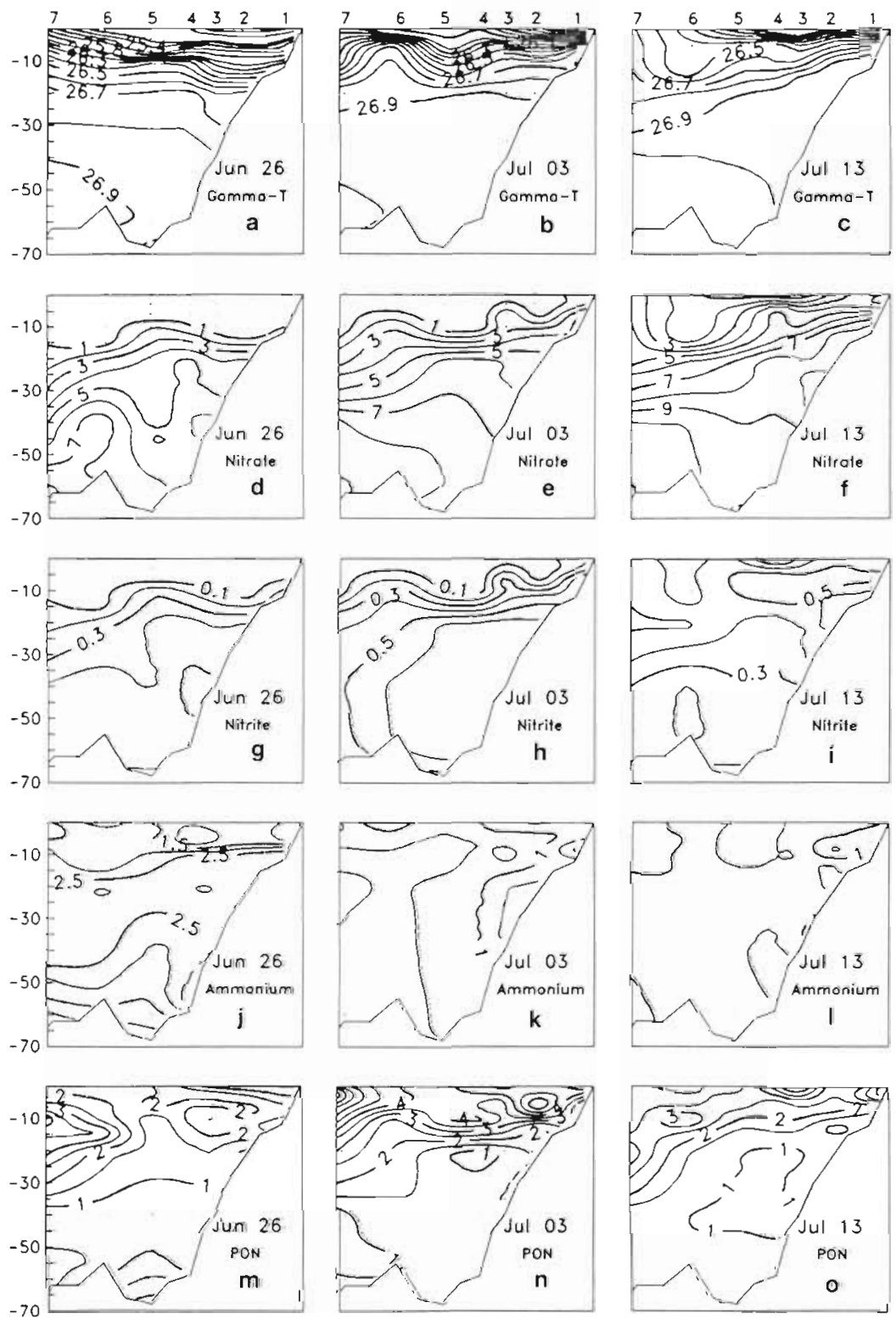

Fig. 2. Representative distributions of $\gamma$, nitrate, nitrite, ammonium and particulate organic nitrogen along the main channel of the Ría de Arousa during the upwelling following the high stratification event from June 26 to July 17, 1989. Nitrogen concentrations given in $\mu \mathrm{mol} \mathrm{kg}{ }^{1}$

\section{RESULTS AND DISCUSSION}

\section{Upwelling following high stratification}

From the beginning of the study period to the end of July (Survey 20) thermal and haline stratification led to a relatively stable water column, by means of both heat exchange and continental runoff. Here we discuss how the Ría de Arousa was affected by an upwelling event under these stability conditions.

On June 26 the hydrographic situation along the main channel of the ría was not that of a wind-forced system. The 26.9 isopycnal which characterized the oceanic Eastern North Atlantic Central Water (ENAW) was confined to the bottom of the outermost stations (Fig. 2a). Average water column stability was relatively high, increasing from $0.9 \mathrm{~min}^{-1}$ at $\operatorname{Stn} 7$ to $3.2 \mathrm{~min}^{-1}$ at Stn 1 . where the River Ulla flowed at $50 \mathrm{~m}^{3} \mathrm{~s}^{-1}$ (Rosón et al. 1991) into the ría, as a tongue clearly observed in the $\gamma$ profile. The computed inward current at Stn 4 (Fig. 3a) was $2.1 \mathrm{~km} \mathrm{~d}^{-1}$ and both advective and diffusive vertical exchange were strongly limited $\left(v_{z}=1.1 \mathrm{~m} \mathrm{~d}^{-1} ; k_{z}=\right.$ $4.6 \mathrm{~m}^{2} \mathrm{~d}^{-1}$ ). Ammonium (Fig 2j) remained high, with a subsurface maxi-

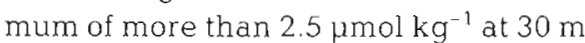
depth, located just below the PON maximum (Fig. $2 \mathrm{~m}$ ). This pattern of vertical distribution agrees with the hypothesis that particulate organic matter (POM) settling from the upper layer is rapidly mineralised, leading to the observed pattern when circulation is slow.

Northerly winds on the shelf enhanced the positive estuarine circulation and on July 3 the 26.9 isopycnul rose to $\sim 25 \mathrm{~m}$, mainly by advection (Fig. $2 b)$. The average Brunt-Väisälä frequency decreased to $0.9 \mathrm{~min}^{-1}$ at $\operatorname{Stn} 4$, 

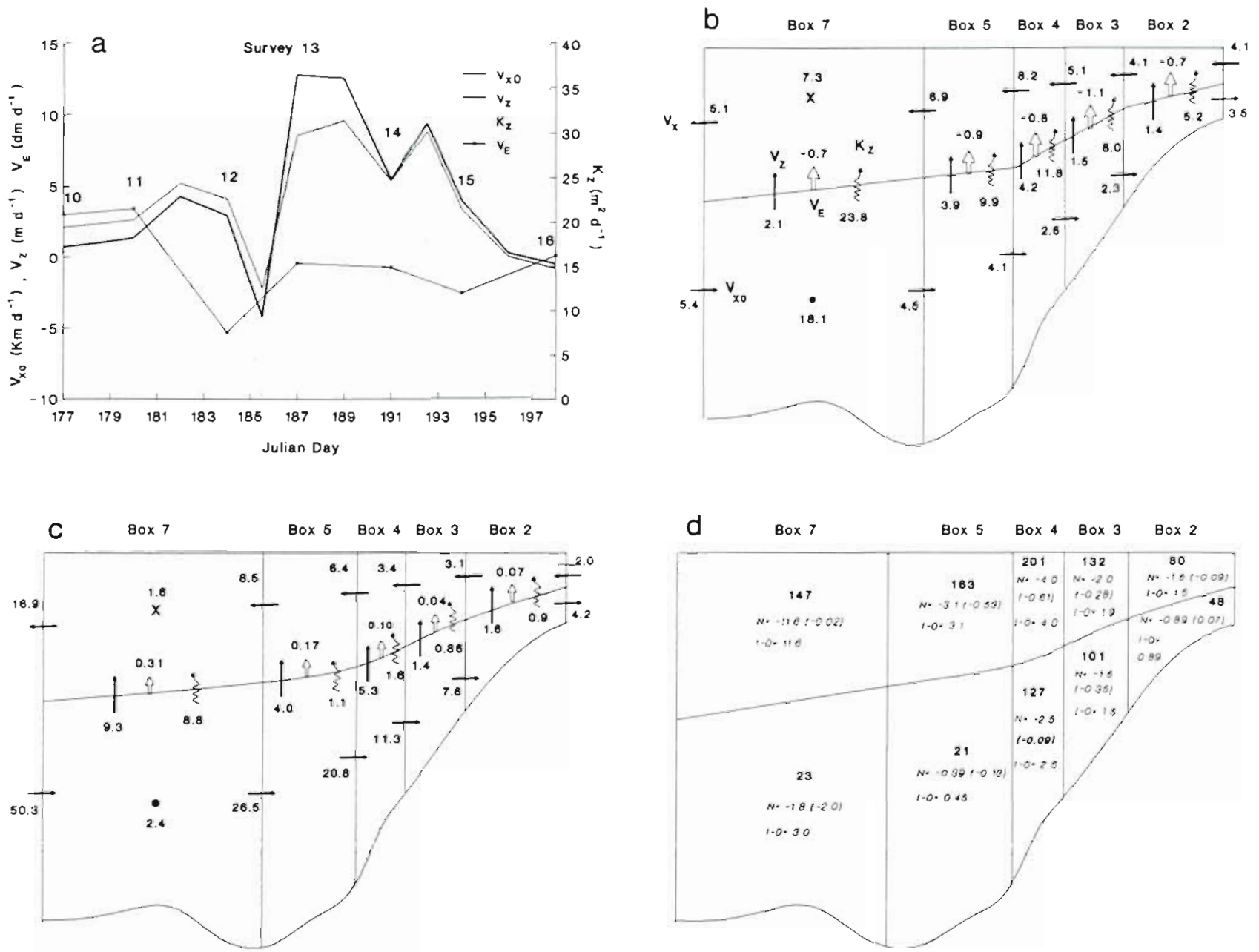

Fig. 3. (a) Time course of inward $\left(v_{X_{0}} ; \mathrm{km} . \mathrm{d}^{-1}\right)$, upward $\left(v_{z} ; \mathrm{m} \mathrm{d}^{-1}\right)$ and entrainment $\left(v_{E} ; \mathrm{dm} \mathrm{d}^{-1}\right)$ velocities and vertical turbulent diffusivities $\left(k_{z} ; \mathrm{m}^{2} \mathrm{~d}^{-1}\right)$ in Box 4 during the upwelling following the high stratification event from June 26 to July 17,$1989 ;(b) v_{x 0}$, $v_{x}, v_{z}, v_{E}$ and $k_{z}$ in each layer of every box averaged over the same period $(c)$ fluxes of dissolved inorganic nitrogen; (d) net budget of inputs - outputs ( $\mathrm{I}-\mathrm{O}$ ) and production (N) of DIN in each layer of every box averaged over the same period. Units are mol $\mathrm{N} \mathrm{s}^{-1}$. Bold numbers (d) correspond to $\mathrm{NCP}\left(\mathrm{mg} \mathrm{N} \mathrm{m}^{-2} \mathrm{~d}^{-1}\right)$ calculated as $\mathrm{NCP}=\mathrm{N} \times 14 \times 1000 \times 86400 /\left(\right.$ box surface area in $\left.\mathrm{m}^{2}\right)$. Values in parentheses indicate net budget of ammonium

while water flow from the shelf was twice that on June 26. Nitrate (Fig. 2e) increased to more than $7 \mu \mathrm{mol} \mathrm{kg}{ }^{-1}$ along the main axis of the ría, below $35 \mathrm{~m}$ depth. In contrast, ammonium (Fig. $2 \mathrm{k}$ ) decreased to $<0.5 \mu \mathrm{mol}$ $\mathrm{kg}^{-1}$, except at the bottom of the inner stations, where the most intense organic matter degradation appears to take place (Figueiras et al. 1986) and concentrations up to $1.5 \mu \mathrm{mol} \mathrm{kg} \mathrm{kg}^{-1}$ were recorded. Nitrite (Fig. 2h) showed an intermediate distribution between nitrate and ammonium. The vertical transport of nitrate, together with stratification in the upper layer, led to an average PON increase of $1.5 \mu \mathrm{mol} \mathrm{kg}{ }^{-1}$ relative to June 26 (Fig. 2n).

During July 6 and 10, wind-driven upwelling persisted and the inward flow increased to $5.4-8.7 \mathrm{~km} \mathrm{~d}^{-1}$. Vertical advection represented $90 \%$ of the upward transport, while turbulent diffusion remained low. As a consequence, on July 13 water denser than 26.9 was observed in the bottom layer of the inner ría (Stn 1), at $10 \mathrm{~m}$ depth (Fig. 2c). Ammonium (Fig. 21) decreased to $<1 \mu \mathrm{mol} \mathrm{kg}^{-1}$ and ENAW containing $>9 \mu \mathrm{mol}$ nitrate $\mathrm{kg}^{-1}$ (Fig. 2f) occupied the lower layer of the whole ría. Upwelling tended to reduce the residence time of water in the upper layer and PON decreased to an average concentration of $2.6 \mu \mathrm{mol} \mathrm{\textrm {kg } ^ { - 1 }}$ (Fig 20)

The velocity field averaged over this upwelling cycle is summarised in Fig. 3b. Inward flows in the outer boxes were $>4 \mathrm{~km} \mathrm{~d}^{-1}$, almost twice those calculated for the inner estuary, due to the abrupt bathymetric change close to Stn 4 (Fig. 1) which constitutes a barrier to the entry of ENAW into the inner ría. Consequently, the highest upward flows were computed 
in Box 4 , which represented $43 \%$ of the inward flow, while $32 \%$ was the average for the entire ría. Therefore, 2 residual circulation cells can be clearly distinguished: the outer one, with rapid residual circulation directly affected by hydrographic changes over the shelf, and the inner one, protected against upwelled water and influenced by the continental input where water moves more slowly. Current meter measurements in the Ría de Vigo over a complete upwelling/ relaxation cycle (Figueiras et al. 1994) gave residual velocities similar to those obtained in this work. Other measurements performed in the Ría de Arousa (Otto 1975, Castillejo \& Lavín 1982) were also similar to our computed values. Turbulent diffusion, which increased shelfward from 5.2 to $23.8 \mathrm{~m}^{2} \mathrm{~d}^{-1}$ in accordance with the decrease in water column stability, constituted $35 \%$ of the total upward water transport over the whole ria and only $22 \%$ in Box 4 . The volume of the upper layer increased at the expense of the lower one, at an average rate of only $8 \mathrm{~cm} \mathrm{~d}^{-1}$; however, the sharpest change occurred during Survey 12 (Fig. 3a). Residence time of water was about $1.3 \mathrm{~d}$ for every box, except for Box 7 . the largest one, where residence time was $2.5 \mathrm{~d}$.

During this upwelling event, an average DIN input of $50.3 \mathrm{~mol} \mathrm{~s}^{-1}$ entered the ria from the shelf (Fig, 3c), making up $94 \%$ of the total input to the volume considered (Boxes 2 to 7 ). The Ulla estuary (Box 1) and the ' $O$ Grove' deep (Box 8 ) had a DIN input of only 2.0 and $1.6 \mathrm{~mol} \mathrm{~s}^{-1}$ respectively. In the outer box, DIN was transported to the upper layer by advection and turbulent diffusion, in equal amounts, while entrainment only represented $1.7 \%$. In the rest of the ria, where water stratification increased, vertical advection accounted for $72 \%$ of the DIN transport from the lower layer. Nitrogen biogeochemistry, i.e. NCP, was mainly responsible $(85 \%)$ for the $8.3 \mathrm{~mol} \mathrm{~s}^{-1}$ of nitrogen that were trapped in the lower layer of the ría. Hydrodynamic accumulation was important only in the outer box, where it represented $40 \%$ of the trapped DIN (Fig 3d). By contrast, in the upper layer the DIN budget resulted completely from uptake by the community of organisms in the ría.

Consequently, during this upwelling cycle the whole ria acted as an efficient nutrientsalt trap: $66 \%$ of the inward flux of DIN from the shelf was retäiñed iñside it, āinù $07 \%$ of this by NCP. Averaged-over-ría NCP was $194 \mathrm{mg} \mathrm{m}^{-2} \mathrm{~d}^{-1}\left(168 \mathrm{mg} \mathrm{m}^{-2} \mathrm{~d}^{-1}\right.$ from net uptake of nitrate), $76 \%$ in the upper layer and $24 \%$ in the lower layer. Box 4 , where upwelling was enhanced by the bathymetry, was the most productive segment (328 $\mathrm{mg} \mathrm{m}^{-2} \mathrm{~d}^{-1}$ ). Prego (1994) obtained a NCP of $144 \mathrm{mg} \mathrm{m} \mathrm{m}^{-2} \mathrm{~d}^{-1}$ during a vigorous upwelling event in the adjacent Ria de Vigo. Entrainment was not a relevant mechanism of vertical transport (Fig. 3c)

Ammonium, which diffused from the sediments (see Fig 10a), contributed $16 \%$ to the pelagic NCP. NCP was mainly transferred to the PON pool $(84 \%)$ in the upper layer and to the DON pool (98\%) in the lower layer Although $\triangle \mathrm{PON}$ (suspended plus settled) was greater than $\triangle \mathrm{DON}$ for the whole ría, this pattern was clearly inverted in the inner boxes (Table 1) The $\triangle D O N / \triangle P O N$ ratio decreased progressively from 1.37 in Box 2 to 0.41 in Box 7 . By contrast, sinking of net produced PON increased from $17 \%$ of $\triangle \mathrm{PON}$ in the innermost to $53 \%$ in the outermost box during this upwelling following the high stratification event, a situation favoured by the 2-layer residual circulation pattern
Table 1. Net biogeochemical budget of the nitrogen species in each box for the 4 characteristic situations studied in the Ría de Arousa, NW Spain. $\triangle D I N$ : budget for dissolved inorganic nitrogen; $\triangle D O N$ : for dissolved organic nitrogen; $\triangle \mathrm{PON}$ : for particulate organic nitrogen (suspended +settled); $\triangle \mathrm{SED}$ : for settled particulate organic nitrogen; $\triangle \mathrm{R}$ : for redissolved inorganic nitrogen (mainly as ammonium). Values are in $\mathrm{mg} \mathrm{N}$ $\mathrm{m}^{-2} \mathrm{~d}^{-1}$; survey numbers are given in parentheses

\begin{tabular}{|c|c|c|c|c|c|c|}
\hline & $\triangle D I N$ & $\Delta(\mathrm{DIN}-\mathrm{R})$ & $\triangle \mathrm{PON}$ & $\triangle D O N$ & $\triangle S E D$ & $\Delta \mathrm{F}$ \\
\hline \multicolumn{7}{|c|}{ Upwelling following high stratification (Surveys 10-16) } \\
\hline Box 2 & -147 & -127 & 62 & 85 & 11 & 20 \\
\hline Box 3 & -239 & -232 & 103 & 137 & 34 & 7 \\
\hline Box 4 & -333 & -328 & 202 & 131 & 87 & 5 \\
\hline Box 5 & -228 & -184 & 123 & 105 & 62 & 44 \\
\hline Box 7 & -184 & -171 & 130 & 54 & 69 & 14 \\
\hline \multicolumn{7}{|c|}{ Upwelling following low stratification (Surveys 29-32) } \\
\hline Box 2 & -78 & -6 & 73 & 5 & 0 & 72 \\
\hline Box 3 & -85 & -54 & 42 & 43 & 2 & 31 \\
\hline Box 4 & -102 & -70 & -26 & 129 & 26 & 32 \\
\hline Box 5 & -48 & 30 & 67 & -19 & 28 & 78 \\
\hline Box 7 & -34 & 22 & -16 & 50 & 0 & 57 \\
\hline \multicolumn{7}{|c|}{ Non-wind-forced condition (Surveys 22-25) } \\
\hline Box 2 & -60 & -22 & 27 & 33 & 28 & 38 \\
\hline Box 3 & -54 & -19 & 29 & 25 & 23 & 34 \\
\hline Box 4 & -33 & 30 & 15 & 18 & 30 & 63 \\
\hline Box 5 & 21 & 66 & -31 & 10 & 22 & 45 \\
\hline Box 7 & 2 & 17 & 3 & -4 & 43 & 15 \\
\hline \multicolumn{7}{|c|}{ Intense autumn downwellnng (Surveys $41-46$ ) } \\
\hline Box 2 & -12 & 7 & 4 & 8 & 11 & 20 \\
\hline $\operatorname{Rnx} 3$ & -27 & 11 & 1.5 & 12 & 23 & 38 \\
\hline Box 4 & 3 & 163 & -82 & 78 & 6 & 160 \\
\hline Box 5 & 26 & 225 & -86 & 60 & 48 & 199 \\
\hline Box 7 & -52 & 50 & -43 & 95 & 24 & 102 \\
\hline
\end{tabular}




\section{Upwelling following low stratification}

From August 3 to the end of the study period, water column stability was supported only by thermal stratification due to the low river discharge (Roson et al. 1995). On August 31 (Survey 29) the distribution of $\gamma$ (Fig. 4 a) contrasted with that of high stability found on June 26 (Fig 2a) Isopycnals were less compressed, with the depth-averaged Brunt-Väisälä frequency, $\langle N\rangle$, ranging from $0.7 \mathrm{~min}^{-1}$ at Stn 7 to $1.0 \mathrm{~min}^{-1}$ at Stn 1. Water denser than 26.9 was not observed inside the ría on August 31 Ammonium (Fig. 4j) showed a distribution pattern typical of slow circulation (Fig. 5a), with concentrations increasing towards the inner part of the ría. Nitrate (Fig. 4d) and nitrite (Fig 4g) were both depleted in the upper layer (average PON of 4.6 umol kg-1; Fig. $4 \mathrm{~m}$ ). In the lower layer, nitrite exhibited a maximum at the bottom of the mid-ría stations, denoting again the existence of rapid nitrification processes in the ria.

After $4 d_{1}$ on September 4 (Survey 30), wind stress over the shelf $\left(I_{\mathrm{w}}=2097 \mathrm{~m}^{3} \mathrm{~s}^{-1} \mathrm{~km}^{-1}\right)$ acted on this hydrographic structure and the situation changed dramatically. Although the inward flows (Fig. 5a) were of the same order as in the previous case studied $\left(v_{\chi_{0}}=6.4 \mathrm{~km} \mathrm{~d}^{-1}\right)$, upward transport occurred by advection $\left(v_{2}=\right.$ $\left.5.4 \mathrm{~m} \mathrm{~d}^{-1}\right)$ and turbulent diffusion $\left(k_{\gamma}=\right.$ $36.4 \mathrm{~m}^{2} \mathrm{~d}^{-11}$ in equal shares. Therefore, strong vertical mixing took place as inferred trom the $\gamma$ distribution (Fig. 4 b), with $\langle N\rangle=0.6 \mathrm{~min}^{-1}$. Water denser than 26.9 appeared below $50 \mathrm{~m}$ depth and the 26.7 reference isopycnal rose by $-15 \mathrm{~m}$ compared to August 31 . Ammonium (Fig. $4 \mathrm{k}$ ) was homogeneously distributed in the entire ría at $\sim 1 \mu \mathrm{mol} \mathrm{kg}{ }^{1}$, while surface nitrate levels $>7 \mu \mathrm{mol} \mathrm{kg}^{-1}$ (Fig. 4e) provided evidence of intense nutrient replenishment by upwelling. PON-rich upper water flushed rapidly to the shelf and was replaced by the nitrate-rich subsurface water.

On September 11 (Survey 32) wind stress dropped $\left(I_{\mathrm{w}}=966 \mathrm{~m}^{3} \mathrm{~s}^{-1} \mathrm{~km}^{-1}\right)$ and flows decreased to those seen on August 31, but the hydrographic structure was quite different. Although the ría was no longer wind-forced, the effects of upwelling still. remained in the water column: below $20 \mathrm{~m}$, the water density was $>26.9$ (Fig. 4c) and nitrate concentration was $>9 \mu \mathrm{mol} \mathrm{kg}{ }^{-1}$ (Fig. 4f). However, the beginning of the upwelling relaxation was indicated by the strong stability observed in the upper layer $\left(1.5 \mathrm{~min}^{-1}\right.$ in the upper $15 \mathrm{~m})$, which allowed phytoplankton to accumulate $\left(\mathrm{PON}>4 \mu \mathrm{mol} \mathrm{kg}{ }^{-1}\right.$ on average; Fig 4o) Ammonium (Fig. 4l) and nitrite (Fig. 4i) distributions were both maximum at the bottom of the innermost stations, which also supports this idea.

During the upwelling cycle following low stratification, residual circulation
Fiq. 4. Representative distributions of $y$, nitrate, nitrite, ammonium and particulate organic nitrogen along the main channel of the Ría de Arousa during the upwelling following the low stratification event from August 31 to September 11. 1989 . Nitrogen concentrations given in $\mu \mathrm{mol} \mathrm{kg} \mathrm{kg}^{-1}$ 

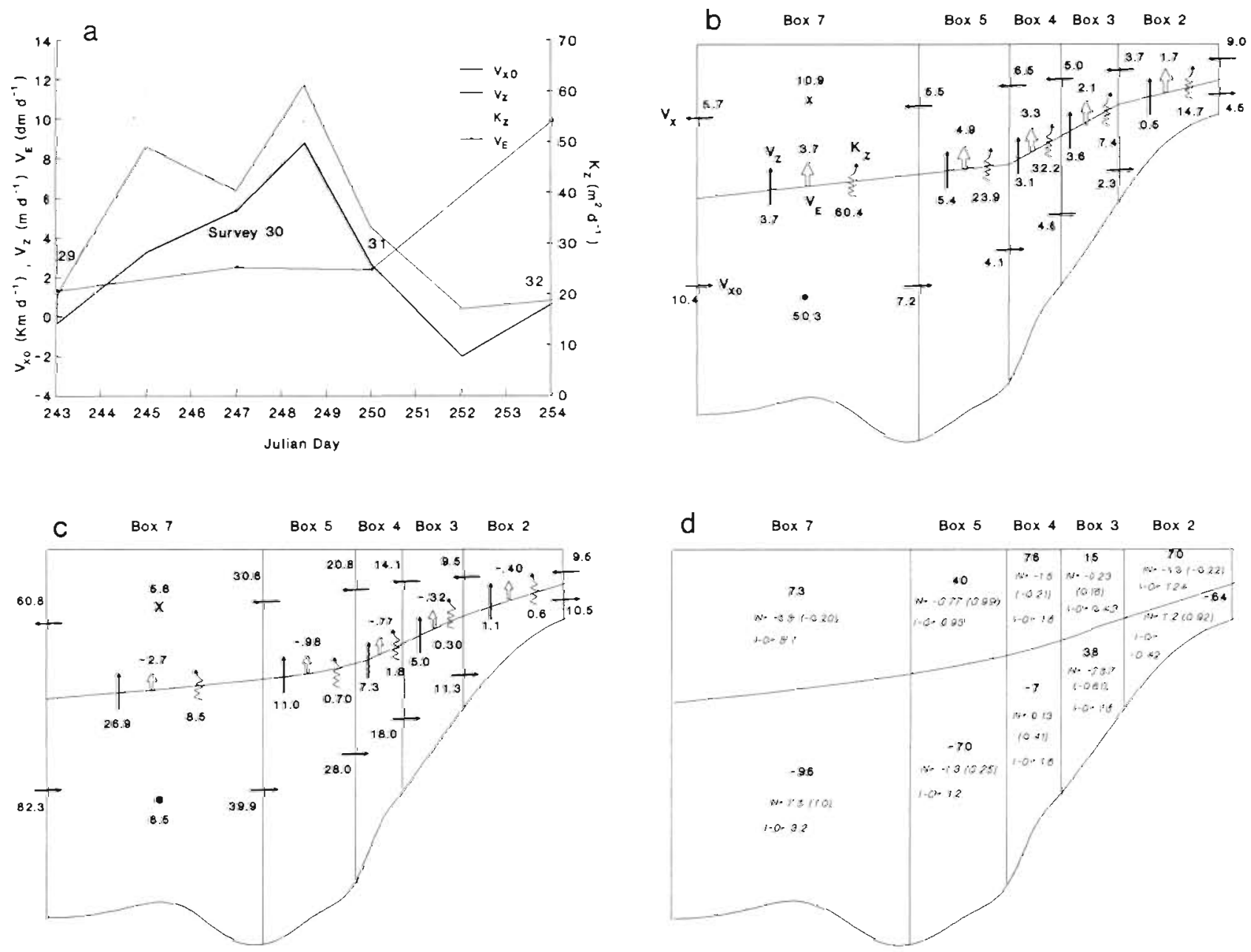

Fig. 5. (a) Time course of inward $\left(v_{X_{0}} ; \mathrm{km} \mathrm{d}^{-1}\right)$, upward $\left(v_{z i} \mathrm{~m} \mathrm{~d}^{-1}\right)$ and entrainment $\left(v_{\mathrm{E}} ; \mathrm{dm} \mathrm{d}^{-1}\right)$ velocities and vertical turbulent diffusivities $\left(k_{i} ; \mathrm{m}^{2} \mathrm{~d}^{-1}\right)$ in Box 4 during the upwelling following the low stratification event from August 31 to September 11 , $1989 ;$ (b) $v_{x 0}, v_{X}, v_{z}, v_{E}$ and $k_{z}$ in every layer of every box averaged over the same period; (c) fluxes of dissolved inorganic nitrogen (d) net budget of inputs - outputs (I-O) and production $(N)$ of DIN in each layer of every box averaged over the same period. Units are mol $\mathrm{Ns}$ ' Bold numbers (d) correspond to NCP $\left(\mathrm{mg} \mathrm{N} \mathrm{m}^{-2} \mathrm{~d}^{-1}\right.$ ) calculated as $\mathrm{NCP}=\mathrm{N} \times 14 \times 1000 \times 86400 /($ box surface area in $\mathrm{m}^{2}$ ). Values in parentheses indicate net budget of ammonium

(Fig 5b) was clearly faster than in the previous case studied. On average over the whole ria, $31 \%$ of the inward flow rose to the upper layer and turbulent diffusion represented $53 \%$ of the upward water transport. However, there were some differences among boxes. While turbulent diffusion represented about $55 \%$ of the upward flow in Boxes 7 and 4 , it was less than $20 \%$ in Boxes 5 and 3. The low density gradient of Box 7 and the topographically induced upwelling in Box 4 suggest the importance of mixing in these boxes. The lower layer invaded the upper one by entrainment at an average rate of $30 \mathrm{~cm} \mathrm{~d}^{1}$, opposite to the behaviour observed during the upwelling versus high stratifica tion event. The response of continental shelf waters of $f$ the Rías Baixas to an upwelling event has also been found to be strongly dependent on freshwater out- welled from the rías and on solar heating (Tenore et al. 1995).

Enhancement of estuarine circulation led to higher DIN fluxes (Fig. 5c): $82.3 \mathrm{~mol} \mathrm{~s}^{-1}$ entered from the shelf during this event, $86 \%$ as nitrate. However, the efficiency of the ria as a nutrient-salt trap was only about $25 \%$. The low initial phytoplankton biomass in the newly upwelled water (Brown \& Field 1986) and the short residence time of water $(\sim 0.7 \mathrm{~d}$, except in Box 7 where it was double), which does not allow complete transition from slow to fast phytoplankton growth in response to high nutrient and light conditions (Barber

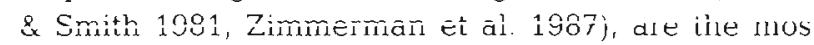
likely reasons for the low phytoplankton growth observed. The percentage of ammonium in the outward fluxes along the ría, 13 to $19 \%$ (not shown), indi- 
cates the reduced phytoplankton activity (Alvarez-Salgado et al. 1996). Averaged NCP (Fig. 5d) in the upper

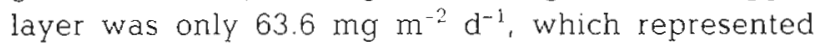
$78 \%$ of the trapped DIN. In the lower layer net DIN regeneration occurred, equalling NCP in the upper layer, and was maximum at Box 7 Consequently, and over the ría as a whole, hydrodynamic accumulation was the mechanism responsible for net DIN retention during this event. An appreciable decrease in the volume of the upper layer led to a considerable DIN transport to the lower layer by entrainment (Fig. 5c), when compared with the net budget of inputs and outputs (Fig. 5d).

DIN, accumulated in the photic layer during this strong upwelling, was subsequently used by phytoplankton when the system relaxed (Fig. 4o), as usually occurs in upwelling areas (Small \& Menzies 1981, Brown \& Field 1986, Peterson et al. 1987, Wilkerson \& Dugdale 1987). However, the most productive conditions occur under conditions of moderate winds, when the photic layer is saturated with upwelled nitrate and the residence time of water is long enough to prevent 'washout', resulting in effective utilisation by phytoplankton (Huntsman \& Barber 1977, Wroblewski 1977, Wroblewski \& Hoffmann 1989). This was the situation during the upwelling following the high stratification event described previously, in which DIN input and uptake took place within the same time scale. This is likely the key to the high productivity inside the rias, where upwelling is not as intense as on the shelf and the upwelled water is distributed over the large volume of these coastal embayments. Along with shelf wind conditions, the productivity of the rias is also determined by the water column stabil. ity immediately prior to the wind-stress pulse, which can control the intensity of upwelling inside the ría.

The biogeochemical budget during this period (see Fig. 10b) showed the low phytoplankton activity in the upper layer, $12 \%$ of which was due to nutrient diffusion from the sediment, with the pelagic NCP maximum again occurring in Box 4, at only $102 \mathrm{mg} \mathrm{m}^{-2}$ $\mathrm{d}^{-1}$ (Table 1). The proportion of net produced DON (35\%) increased relative to the previous event. In the lower layer most of the sinking PON was degraded to DON $(57 \%)$ and DIN ( $43 \%$ ), although the main source of regenerated DIN was the sediment.

\section{Non-wind-forced system}

We examined the evolution of nitrogen species during a period of $10 \mathrm{~d}$ without wind forcing after an upwelling event. Distributions of $\gamma($ Fig. 6a, b, c) on the surveys selected $(22,23$ and 25$)$ indicated a slow relaxation of the system, with ENAW moving shelfward.
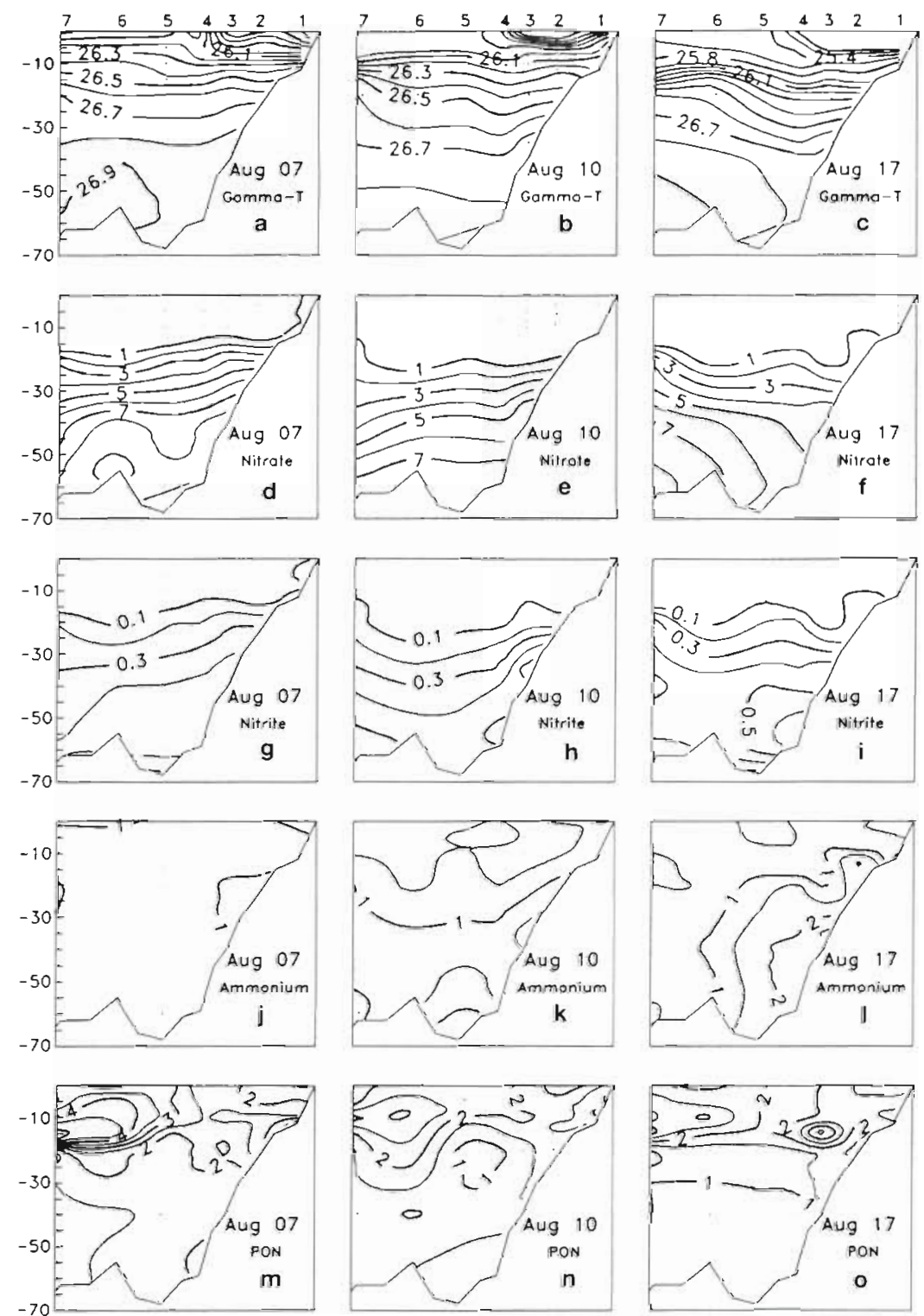

Fig. 6. Representative distributions of $\gamma$, nitrate, nitrite, ammonium and particulate organic nitrogen along the man channel of the Ria de Arousa during the upwelling relaxation from August 7 to 17, 1989. Nitrogen concentrations given in $\mu \mathrm{mol} \mathrm{kg}^{-1}$ 

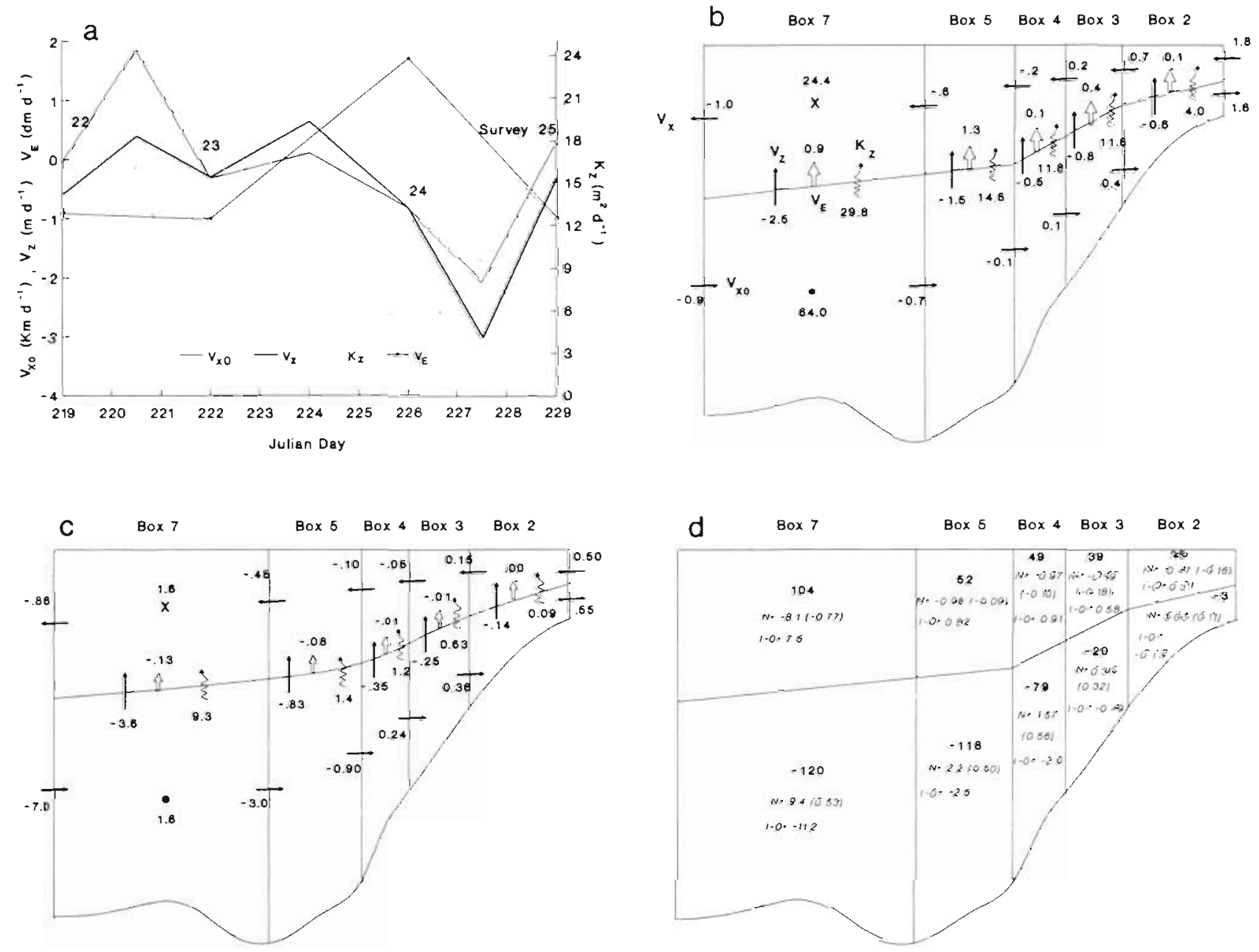

Fig. 7 (a) Time course of inward $\left(v_{x_{0}} ; \mathrm{km} \mathrm{d}^{-1}\right)$, upward $\left(v_{z} ; \mathrm{m} \mathrm{d}^{-1}\right)$ and entrainment $\left(v_{E} ; \mathrm{dm} \mathrm{d}^{-1}\right)$ velocities and vertical turbulent diffusivities $\left(k_{z i} \mathrm{~m}^{2} \mathrm{~d}^{-1}\right)$ in Box 4 during the upwelling relaxation from August 7 to 17,$1989 ;$ (b) $v_{X 0}, v_{X}, v_{z,}, v_{E}$ and $k_{z}$ in every layer of every box averaged over the same period; (c) fluxes of dissolved inorganic nitrogen; (d) net budget of inputs - outputs (I - O) and production $(N)$ of DIN in each layer of every box averaged over the same period. Units are mol $\mathrm{N} \mathrm{s}^{-1}$. Bold numbers (d) correspond to $\mathrm{NCP}\left(\mathrm{mg} \mathrm{N} \mathrm{m}^{-2} \mathrm{~d}^{-1}\right.$ ) calculated as $\mathrm{NCP}=\mathrm{N} \times 14 \times 1000 \times 86400 /\left(\right.$ box surface area in $\left.\mathrm{m}^{2}\right)$. Values in parentheses indicate net budget of ammonium

Averaged residual circulation over this period (Fig. 7b) was extremely weak, with $v_{x 0}$ ranging from -1.0 to $1.6 \mathrm{~km} \mathrm{~d}^{-1}$. The residence time of water was $5 \mathrm{~d}$ in the inner Boxes 2 and 3, where the ría acts as a positive estuary, and $10 \mathrm{~d}$ in the outer ones, where slightly reversed mean flows occurred, indicating advection of warmer shelf surface water into the ría in response to relaxed winds. There are again 2 clearly different circulation patterns for the inner and outer ria. The expected reversal of surface circulation in upwelling areas during wind relaxations (Peterson et al. 1987) was observed from current meter measurements in the Ría de Vigo (Figueiras of al 1994) Vertical transport was strongly limited, with a net downward flow of 0.5 to $2.5 \mathrm{~m} \mathrm{~d}^{-1}$ and low coefficients of turbulent diffusion ranging from $4.0 \mathrm{~m}^{2} \mathrm{~d}^{-1}$ in Box 2 to $29.8 \mathrm{~m}^{2} \mathrm{~d}^{-1}$ in Box 7 because of the high water column stability, $\langle N\rangle=0.77$ to $1.19 \mathrm{~min}^{-1}$. Entrainment to the lower layer occurred at the extremely slow rate of $5 \mathrm{~cm} \mathrm{~d}^{-1}$ (Fig. 7b). The time course of the ammonium distribution (Fig. 6j, k, l) was as expected when relaxation of upwelling takes place. Concentration increased from $<1.0 \mu \mathrm{mol} \mathrm{kg} \mathrm{kg}^{-1}$ in the whole ría on August 7 to more than $2.0 \mu \mathrm{mol} \mathrm{kg} \mathrm{kg}^{-1}$ at the bottom of the inner stations on August 17 Mineralization inside the ria led to the development of a nitrite maximum ( $>0.5 \mu \mathrm{mol} \mathrm{kg}^{-1}$ ) at the bottom of Stns 4 and 5 (Fig. 6g, h, i). In addition, temporal changes in the

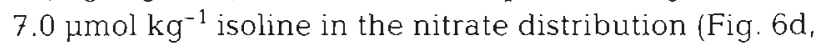

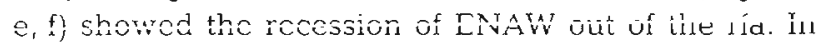
the upper layer, both nitrate and nitrite were depleted (DIN $<1.0 \mu \mathrm{mol} \mathrm{kg} \mathrm{kg}^{-1}$ above $20 \mathrm{~m}$ depth) and the minimal nutrient replenishment from the lower layer 
occurred exclusively by turbulent diffusion, $83.7 \mathrm{mg}$ $\mathrm{m}^{-2} \mathrm{~d}^{-1}$ (Fig. $7 \mathrm{c}$ ) over the whole ria. PON remained low (Fig. 6m, n, o) during these $10 \mathrm{~d}$ of nutrient-limited photosynthetic activity in the upper layer

NCP averaged over the upper layer was $73.8 \mathrm{mg}$ $\mathrm{m}^{-2} \mathrm{~d}^{-1}$ (Fig. 7d) Wroblewski's (1977) model predictions of gross primary production off Oregon (USA) decrease from about $300 \mathrm{mg} \mathrm{N} \mathrm{m}^{-2} \mathrm{~d}^{-1}$ for upwelling conditions to $78 \mathrm{mg} \mathrm{m}^{-2} \mathrm{~d}^{-1}$ after prolonged (10 d) wind relaxation. For the less productive Ría de Vigo, Prego (1994) obtained a NCP of only $25.0 \mathrm{mg} \mathrm{m}^{-2} \mathrm{~d}^{-1}$ during an upwelling relaxation event, $25 \%$ of the value during strong up welling events. Hanson et al. (1986) found that photosynthetic rates de-

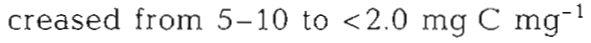
chla $\mathrm{h}^{-1}$ after a spring upwelling event in the Ría de Arousa. NCP increased shelfward corresponding with the progressive decrease of water column stability and, consequently, higher DIN supply by turbulent diffusion. NCP in the upper layer slightly exceeded the DIN budget and therefore DIN previously accumulated in the ría was needed to support NCP; this previously accumulated DIN accounted for $9 \%$ of NCP. On the other hand, net regeneration of $90.0 \mathrm{mg} \mathrm{m} \mathrm{m}^{-2} \mathrm{~d}^{-1}$ occurred in the lower layer, decreasing from the outer to the inner boxes. This spatial difference can be attributed to the residence time of organic matter in the lower layer, which is longer in the deeper outer boxes. Longer residence times allowed more efficient regeneration mainly to nitrate in the outer boxes $\left(88 \% \mathrm{NO}_{3}{ }^{-}\right.$in Boxes 5 to 7 ) and to ammonium in the inner ones $(100 \%$ $\mathrm{NH}_{4}{ }^{+}$in Boxes 2 and 3). As much as $83 \%$ of the DIN exported from the lower layer of the ría to the shelf bottom waters (Fig. 7d) was derived from net regeneration. Hydrodynamic losses made up the remaining $17 \%$. Consequently, for this period, the whole ría did not act as a nutrient-salt trap but as a regeneration system that exported a net amount of $6.2 \mathrm{~mol} \mathrm{~s}^{-1}$ of DIN ( $89 \%$ as nitrate) to the bottom layer on the shelf.

Pelagic NCP in the upper layer during this period acted primarily to increase the DON pool (55\% of NCP). On the other hand, $97 \%$ of PON pro- duced in the upper layer settled over the bottom, preventing any net export to the adjacent shelf (Fig 10c). In the lower layer, DIN increased at the expense of both DON and PON, as did the contribution from the sediments ( $10 \%$ of total $\triangle D I N) . \triangle P O N$ and $\triangle D O N$ progressively decreased shelfward (Table 1) in accordance with the increasing net community regeneration in the lower layer $\mathrm{NCP}$ in the upper layer occurred at the expense of nutrients that were regenerated in the lower layer, at the sediment-water interface.
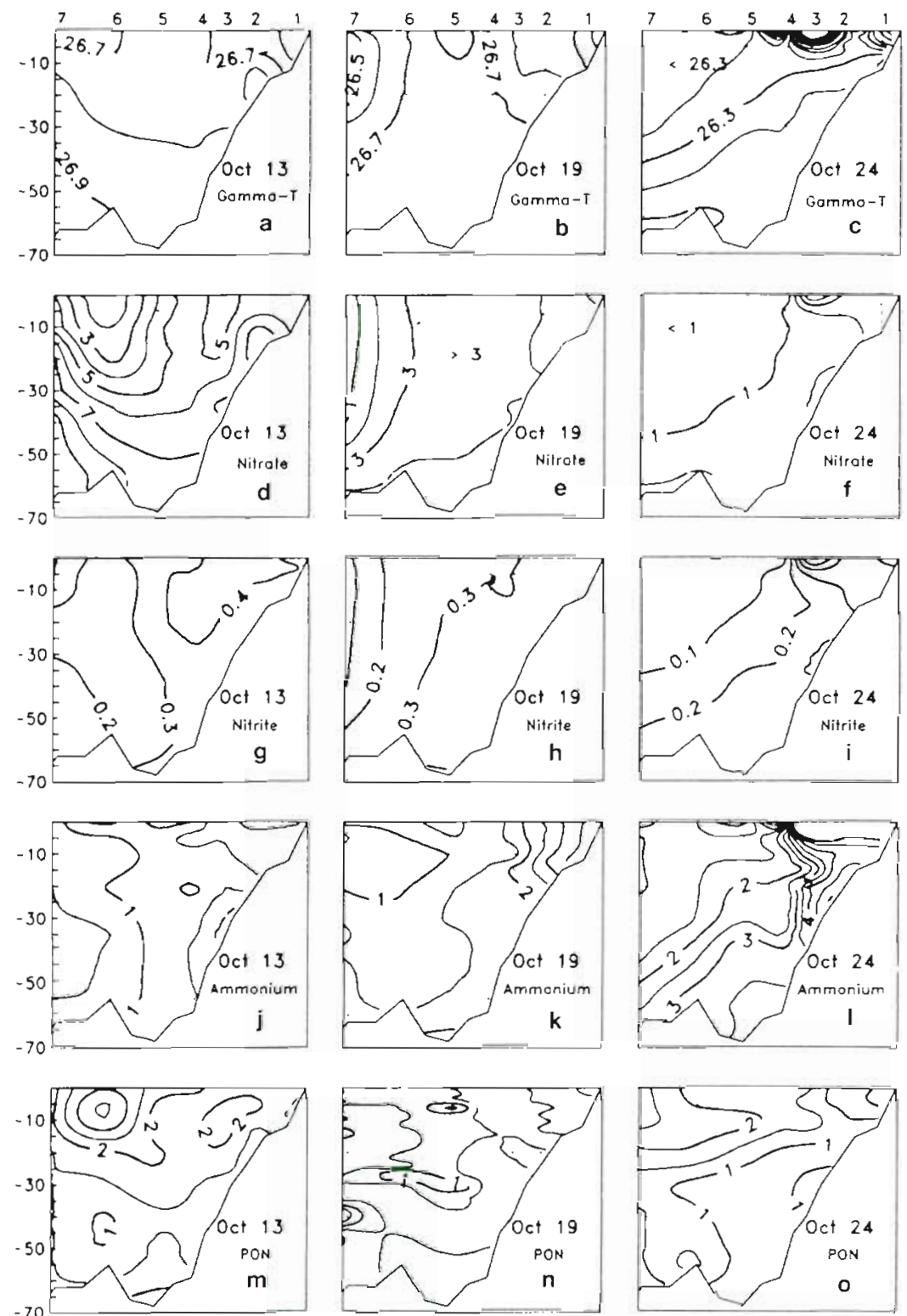

Fig. 8. Representative distrbutions of $\gamma_{1}$ nitrate, nitrite, ammonium and particulate organic nitrogen along the main channel of the Ría de Arousa during the autumn downwelling event from October 9 to 30, 1989. Nitrogen concentrations given in $\mu \mathrm{mol} \mathrm{kg}^{-1}$ 

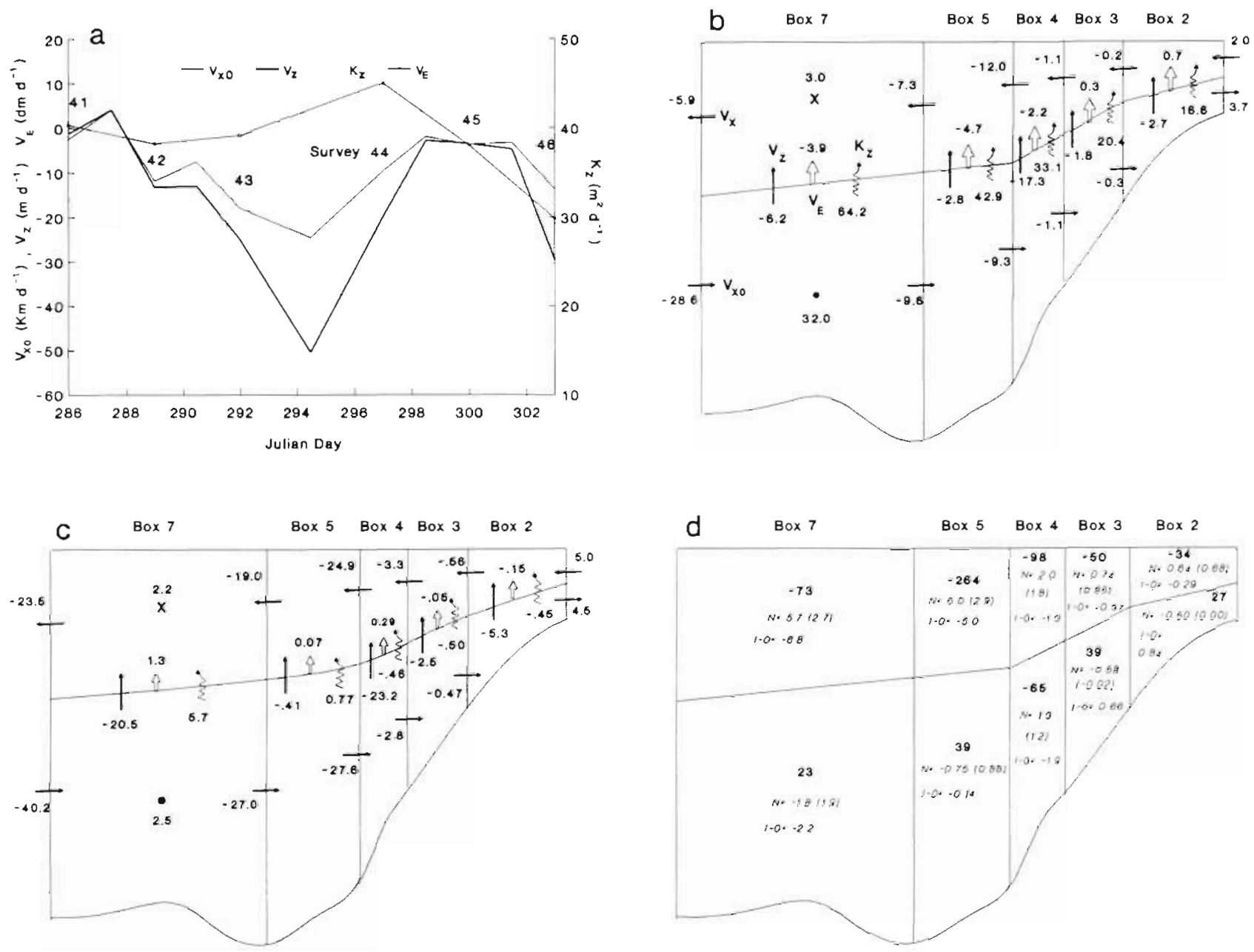

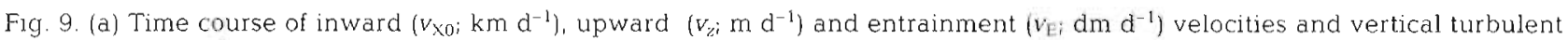
diffusivities $\left(k_{z i} \mathrm{~m}^{2} \mathrm{~d}^{-1}\right)$ in Box 4 during the autumn downwelling event from October 9 to 30,$1989 ;$ (b) $v_{X 0}, v_{X}, v_{Z}, v_{E}$ and $k$, in every layer of every box averaged over the same period ${ }_{i}(c)$ fluxes of dissolved inorganic nitrogen; ( $d$ ) net budget of inputs - outputs $(\mathrm{I}-\mathrm{O})$ and production $(\mathrm{N})$ of DIN in each layer of every box averaged over the same period. Units are mol $\mathrm{N} \mathrm{s}^{-1} \mathrm{Bold}$ numbers (d) correspond to $\mathrm{NCP}\left(\mathrm{mg} \mathrm{N} \mathrm{m} \mathrm{N}^{-2} \mathrm{~d}^{-1}\right.$ calculated as $\mathrm{NCP}=\mathrm{N} \times 14 \times 1000 \times 86400 /$ (box surface area in $\mathrm{m}^{2}$ ). Values in parentheses indicate net budget of ammonium

\section{Intense autumn downwelling}

From October 13 to the end of the study period an intense downwelling event took place (mean $I_{\mathrm{w}}=-950$ $\mathrm{m}^{3} \mathrm{~s}^{-1} \mathrm{~km}^{-1}$ ) over the adjacent shelf (Alvarez-Salgado et al. 1993). This coincided with the characteristic transition from northerly to southerly winds in these latitudes (Wooster et al. 1976, Blanton et al. 1987). Downwelling induced reversed residual circulation for more than $20 \mathrm{~d}$. The sequence of $\gamma$ distributions shows how the water inside the ría was progressively replaced by warmer and less saline shelf surface waters (Fig. 8). At the heginning of this process, a weak reversal in estuarine circulation with subsurface waters moving shelfward at $2.4 \mathrm{~km} \mathrm{~d}^{-1}$ was observed at Stn 4 (Fig. 9a). Nitrate distribution showed a tongue of nutrient-poor shelf surface waters entering the ría, replacing water that contained $>7.0 \mu \mathrm{mol} \mathrm{kg}{ }^{-1}$ (Fig. $8 \mathrm{~d}$, e). The nitrate minimum at the surface layer at Stn $6\left(<1.0 \mu \mathrm{mol} \mathrm{kg}{ }^{-1}\right)$ corresponded to a PON maximum, $>4.0 \mu \mathrm{mol} \mathrm{kg}{ }^{-1}$ (Fig $8 \mathrm{~m}$ ) advected from the shelf. Ammonium (Fig. 8j) and nitrite (Fig. $8 \mathrm{~g}$ ) remained low over the entire ría, but increased towards the inner stations.

Northward wind stress over the shelf increased during the following days to $-1707 \mathrm{~m}^{3} \mathrm{~s}^{-1} \mathrm{~km}^{-1}$ on October 19. During this time, intense reverse flows were calculated and water column stability reached its minimum $\left.(<N\rangle=0.06 \mathrm{~min}^{-1}\right)$. The effect of this persistent downwelling on tho hrdrographic structure can be cleariy observed in the $\gamma$ and nutrient-salt distributions. A vertically homogeneous density profile at the middle stations, caused by bathymetric enhancement of down- 
ward flow (Fig. 8b), and a tongue of nitrogen salt-poor water occupying most of the water column (Fig. $8 e, h, k$ ) were clearly observed. However, ammonium distribution showed a sharp increase to more than $3.5 \mu \mathrm{mol}$ $\mathrm{kg}^{-1}$. PON decreased to $1.0 \mu \mathrm{mol} \mathrm{kg}^{-2}$, as the low residence time of water $(0.5 \mathrm{~d}$ in both the upper and lower layer of Box 4, averaged over this event) did not allow phytoplankton to accumulate.

On October 24, although wind stress $\left(-225 \mathrm{~m}^{3} \mathrm{~s}^{-1}\right.$ $\mathrm{km}^{-1}$ ) and water flows diminished, the hydrographic structure was consistent with the persistent southerly winds; water denser than 26.5 was not present inside the ria (Fig. 8c). Nitrate (Fig. 8f) and nitrite (Fig. 8i) remained below 1 and $0.2 \mu \mathrm{mol} \mathrm{kg}^{-1}$ respectively in almost the entire ría, and the highest ammonium (Fig 8 I) concentration $\left(11.0 \mu \mathrm{mol} \mathrm{kg}^{-1}\right.$ at salinities less than $34 \mathrm{psu}$ ) was recorded at the surface of Stns 1 and 2 , transported from the innermost part of the estuary where an intense mineralization of macrophytes occurred (Pérez et al. 1992).

The average distribution of residual flows along the main channel of the Ría de Arousa (Fig. 9b) showed a clear reversal in water circulation, except for the innermost station. Consequently, the inner and outer rías were again hydrographically distinct. Higher flows were computed in the outer stations, and Box 4 was again found to be the boundary between both circulation cells. The highest downward flow, averaged over this wind-driven downwelling event, was estimated for this box; strong vertical mixing also occurred. Water piling, caused by intense southerly winds at the mouth of the ría (Blanton et al. 1984), was not compensated for the weak river plume in the inner estuary, and thus the ría was forced into a state of negative circulation (Rosón et al. in press). Entrainment occurred at an average rate of $35 \mathrm{~cm} \mathrm{~d}^{-1}$, tending to increase the volume of the upper layer at the outer stations. A similar hydrographic situation was described by Tilstone et al. (1994) in the 4 Rías Baixas, where they observed convergence of the 2 opposite flows.

Average DIN fluxes (Fig. 9c) were in obvious agreement with the circulation pattern. Ammonium now represented about $50 \%$ of DIN in each type of flux. The ria exported nitrogen salts at a net rate of $16.5 \mathrm{~mol}$ $\mathrm{s}^{-1}(43 \%$ as ammonium). DIN regenerated in the upper layer, $106.0 \mathrm{mg} \mathrm{m}^{-2} \mathrm{~d}^{-1}$ (Fig. 9d), was mainly ammonium from the sediments at the continental boundaries (Fig. 10d) and equalled the hydrodynamic losses observed in the upper layer. This regenerated ammonium was transferred to the lower layer and from there to the shelf by the rapid, reversed estuarine circulation. The circulation pattern was also responsible for the intense settling into the lower layer of PON advected from the shelf. Low NCP occurred in the lower layer of the Ría de Arousa (Fig. 9d) during this autumn event.
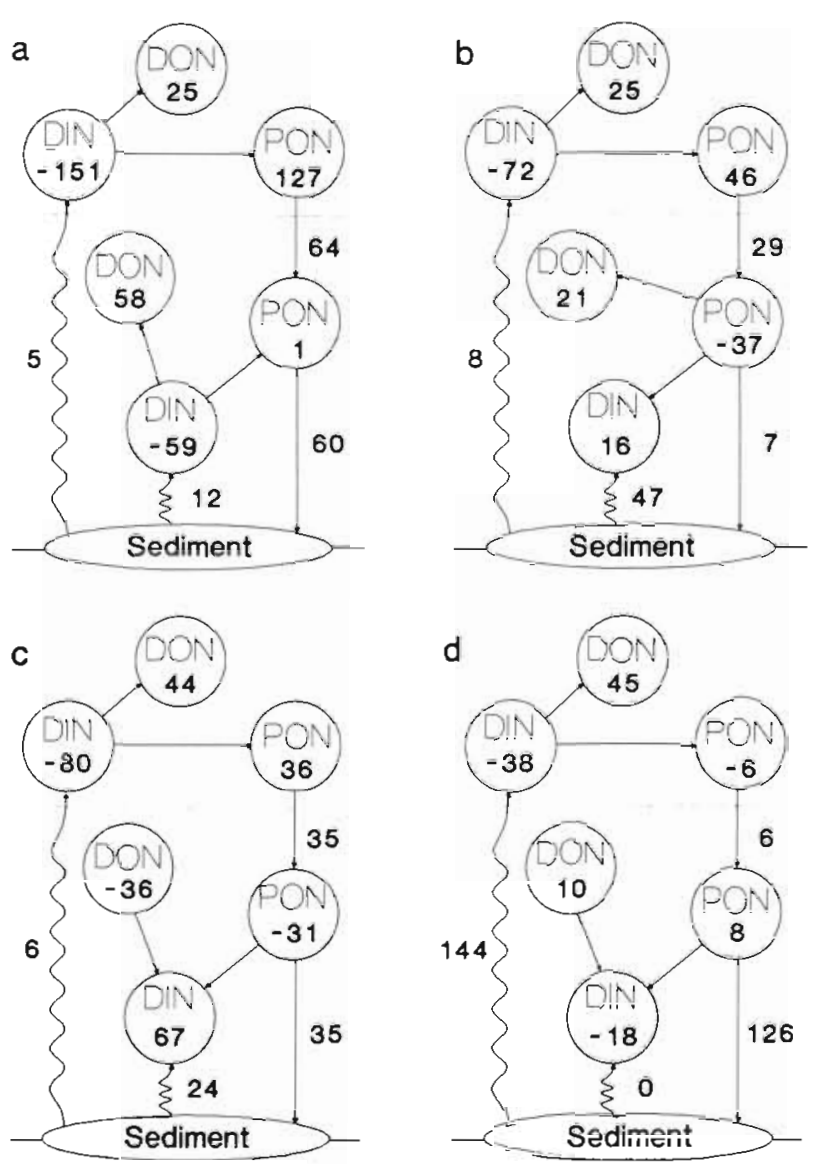

Fig. 10. Net biogeochemical budget for both layers averaged over the whole ria during the study period. (a) Upwelling versus high stratification; (b) upwelling versus low stratification; (c) upwelling relaxation; (d) autumn downwelling. Values are in $\mathrm{mg} \mathrm{N} \mathrm{m} \mathrm{m}^{-2} \mathrm{~d}^{-1}$

DIN transported upwards by entrainment (Fig. 9a) represented $13 \%$ of the total losses in the upper layer

\section{SUMMARY AND CONCLUSIONS}

Energy inputs from wind stress over the shelf and local irradiance primarily determine water circulation and mixing patterns inside the Rías Baixas, as usually occurs in upwelling systems (Margalef 1978). These large coastal embayments allow increased residence time of the upwelled water in the photic layer and, in comparison with the adjacent shelf surface waters, enhance the influence of solar heating on thermocline formation and of phytoplankton on nutrient uptake.

The characteristic wind-forced estuary-like water circulation in upwelling areas determines, both quantitatively and qualitatively, nitrogen fluxes in the rías during the upwelling season. Water column stability prior to upwelling acts as a buffer against upwelling 
intensity and determines: (1) the prevalent physical mechanism of nitrate transport to the photic layer; (2) the lag time between input and net biological uptake; and (3) the efficiency of the ría as a nutrientsalt trap. In conditions of high stratification, vertical advection lifts nitrate to the photic layer, where uptake occurs simultaneously and the ría acts as an efficient nutrient-salt trap by biogeochemical processes. For the 'model' case studied, a NCP of $194 \mathrm{mg} \mathrm{m}^{-2} \mathrm{~d}^{-1}$ was responsible for trapping $66 \%$ of the DIN input from the shelf. This situation is equivalent to one of moderate winds, which is the most productive condition as for upwelling systems. However, when stratification prior to upwelling is slight, vertical mixing prevails, upwelled nutrients are trapped by hydrodynamic accumulation and efficiency is dramatically reduced. In this situation, net nutrient uptake by phytoplankton is delayed, as usually occurs during strong upwelling events, because cell concentration in upwelled waters is low and the lag time for adaptation to the nutrient and light conditions exceeds the residence time of water. Nitrogen biogeochemistry is also strongly affected by stratification prior to the upwelling event. When water column stability remains high, pelagic NCP occurs in the entire water column and nitrogen partitioning is dominated by the PON pool in the upper layer and by the DON pool in the lower layer: $1 / 3$ of NCP settles to the bottom. However, during strong upwelling, DIN uptake by low NCP in the upper layer is compensated for by net community regeneration (partly from degradation of settled PON) and by the contribution from the sediments in the lower layer.

The situation is quite different when prolonged periods of relaxation occur between successive upwelling events. Strong water-column stratification develops and vertical transport (advective, diffusive and by entrainment) is rather limited. In conditions without wind forcing, the PON increase in the upper layer is controlled by low nutrient supply from the lower layer (the only source of DIN), and NCP dramatically diminishes. In the case studied, NCP in the upper layer is half that in upwelling + stratification conditions. NCP can be completely supported by DIN regenerated in the lower layer and at the sediment-water interface, since the latter equals net DIN consumption in the upper layer Because of slow residual currents, organic matter is not exported to the shelf, but sinks inside the ría $(97 \%$ of the organic matter produced in the upper layer). In addition, residence time of water is long enough ( 5 to $10 \mathrm{~d}$ ) to allow ammonium diffusing from the sediment at high rates to accummlate in the lower layer, increasing in concentration toward the inner estuary. Nitrate concentration decreases as ENAW moves toward the shelf.
During the transition from northerly to southerly winds, a strong downwelling event forces shelf surface waters into the inner ría, where the reversed flow meets with ammonium-rich waters coming from the Ulla estuary. This advected ammonium, combined with that diffused from the sediments, is transported to the bottom layer over the shelf by the reversed residual circulation. High sedimentation rates result from intense transport of PON (not shown) to the lower layer, by both strong advection and turbulent diffusion.

In any of the 4 representative hydrographic scenarios presented, 2 cells of circulation can be clearly distinguished. In the outer one, open to the ocean's influence, water moves rapidly and follows the variability imposed by shelf wind stress. In the inner one, which is topographically protected from the direct entry of upwelled flow, water is displaced more slowly. The central segment of the ria, where the abrupt bathymetric change occurs, is the boundary between the 2 circulation cells. It undergoes the most intense water dynamics, being the most productive segment of the ria.

Acknowledgements. The authors thank all the participants in the GALICIA-X cruise, especially T Rellán and R. Penin, for their unconditional devotion. We are also very grateful to the crew of the RV 'Investigador S: who were always ready to help us. Support for this work came from C.I.C.Y.T. Grant No. MAR88-0245 and funds from the Conselleria de Pesca da Xunta de Galicia. Fellowships from the Spanish M.E.C. enabled X.A.A.-S and G.R. to carry out their Ph.D. theses as part of this project. We also thank Dr E. Fernández for his valuable comments and criticisms and Dr A. Miller for correction of the English. Prof K. Tenore, Prof. D. Wiegert and 3 anonymous reviewers provided valuable criticisms of the manuscript

\section{LITERATURE CITED}

Alvarcz-Salgado XA, Rosón G, Pérez FF, Figueiras FG, Pazos $Y$ (1996) Nitrogen cycling in an estuarine upwelling system, the Ría de Arousa (NW Spain). I. Short-time-scale patterns of hydrodynamic and biogeochemical circulation. Mar Ecol Prog Ser 135:259-273

Alvarez-Salgado XA, Rosón G, Pérez FF, Pazos Y (1993) Hydrographic variability off the Rias Baixas (NW Spain) during the upwelling season. J Geophys Res 98(C8) $14447-14455$

Barber RT, Smith RL (1981) Coastal upwelling ecosystems. In: Longhurst AR (ed) Analysis of marine systems. Academic Press, San Diego, p 31-68

Blanton JO, Atkinson LP, Castillejo FF, Lavín A (1984) Coastal upwelling off the Rías Bajas, Galicia, Northwest Spain, I: Hydrographic studies. Rapp P-V Réun Cons Int Explor Mer 183:79-90

Blanton JO, Tenore KR, Castillejo FF, Atkinson LP, Schwing FB, Lavín A (1987) The relationship of upwellıng to mussel production in the rías on the western coast of Spain. J Mar Res 45:497-511

Brown PC, Field JG (1986) Factors limiting phytoplankton production in a nearshore upwelling area. J Plankton Res 8:55-68

Castillejo FF, Lavín A (1982) Contribución al estudio del flujo 
de agua entrant': y saliente en la Ría de Arosa. Bol Inst Esp Oceanogr 7:163-180

Figueiras $\mathrm{FG}_{\text {, }}$ Jones KJ, Mosquera AM, Alvarez-Salgado XA, McDougall N (1994) Red tide assemblage formation in a estuarine upwelling ecosystem: Ría de Vigo. J Plankton Res 16:857-878

Figueiras FG, Niell FX, Mounno C (1986) Nutrientes y oxígeno en la Ría de Pontevedra (NO de España). Invest Fesq 50:97-115

Hanson RB, Alvarez-Ossorio MT, Cal R, Campos MJ, Román M, Santiago G, Varela M, Yoder JA (1986) Plankton response following a spring upwelling event in the Ría de Arosa, Spain. Mar Ecol Prog Ser 32: $101-113$

Huntsman SA, Barber RT (1977) Primary production off northwest Africa: the relationship to wind and nutrient conditions. Deep Sea Res 24:25-33

Margalef R (1978) Life forms of phytoplankton as survival alternatives in an unstable environment. Oceanol Acta 1: 493-509

Otto L (1975) Oceanography of the Ría de Arousa (NW Spain). Konink Meteor Int Med Verlan 96

Pérez FF, Alvarez-Saigado XA, Rosón G, Rius AF (1992) Carbonic-calcium system, nutrients and total organic nitrogen in continental runoff to the Galician Rias Baixas, NW Spain. Oceanol Acta 15:595-602

Peterson WT, Arcos DF, McManus GB, Dam H, Bellantoni D, Johnson T, Tiselius $P$ (1987) The nearshore zone during coastal upwelling: daily variability and coupling between primary and secondary production off central Chile. Prog Oceanogr 20:1-40

Prego R (1994) Nitrogen interchanges generated by biogeochemical processes in a Galician ría. Mar Chem 45: $167-176$

Rosón G, Alvarez-Salgado XA, Pérez FF (in press) A nonsteady state box model to determine residual flows in a

This article was submitted to the editor partially mixed estuary based on both thermohaline properties. Estuar Coast Shelf Sci 41:195-213

Roson G, Pérez FF, Alvarez-Salgado XA. Figueiras FG (1995) Variation of both thermohaline and chemical properties in an estuarine upwelling ecosystem: Ria de Arousa. I. Temporal evolution. Estuar Coast Shelf Sci 41:195-213

Rosón G, Pérez FF, Alvarez-Salgado XA, Ríos AF (1991) Flujos de los aportes de agua continental a la Ría de Arosa Scientia Mar 55:583-589

Small LF, Menzies DW (1981) Patterns of primary productivity and biomass in a coastal upwelling region. Deep Sea Res 28:123-149

Tenore KR, and 18 co-authors (1995) Fisheries and oceanography off Galicia, NW Spain (FOG): mesoscale spatial and temporal changes in the physical processes and resultant patterns of biological productivity. J Geophys Res $100(\mathrm{C} 6)$ $10943-10966$

Tilstone GH, Figueiras FG, Fraga F (1994) Upwelling-downwelling sequences in the generation of red tides in a coastal upwelling system. Mar Ecol Prog Ser 112:241-253

Wilkerson FP, Dugdale RC (1987) The use of large shipboard barrels and drifters to study the effect of coastal upwelling on phytoplankton dynamics. Limnol Occanogr 32: 368-382

Wooster WS, Bakun A, McLain DR (1976) The seasonal upwelling cycle along the eastern boundary of the North Atlantic. J Mar Res 34:131-141

Wroblewski JS (1977) A model of phytoplankton plume formation during variable Oregon upwelling. J Mar Res 35: $357-393$

Wroblewski JS, Hoffmann EE (1989) U.S. interdisciplinary modeling studies of coastal-offshore exchange processes: past and future. Prog Oceanogr 23: 65-99

Zimmerman RC, Kremer JN, Dugdale RC (1987) Acceleration of nutrient uptake by phytoplankton in a coastal upwelling ecosystem: a modeling analysis. Limnol Oceanogr $32: 359-367$

Manuscript first recerved: January 25, 1995

Revised version accepted: November 21, 1995 